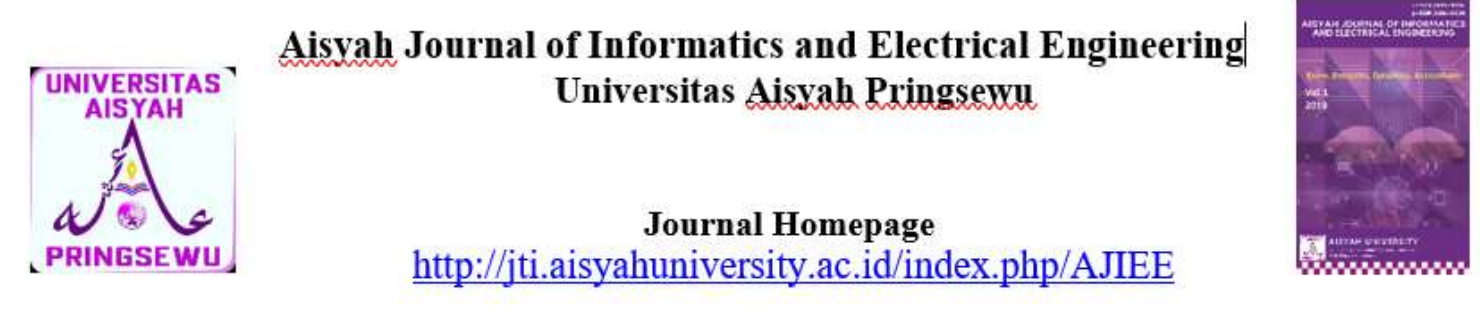

\title{
Analisa Metode Fuzzy Mamdani Dan Sugeno Untuk Deteksi Daerah Rentan Banjir : Studi Kasus Kecamatan Pringsewu
}

\author{
Agustinus Eko Setiawan', Azri Afdhalludin ${ }^{2}$ \\ ${ }^{1,2}$ Program Studi Teknik Informatika, Fakultas Teknologi dan Informatika \\ Universitas Aisyah Pringsewu \\ E-mail:tynuskicenk@gmail.com
}

\begin{abstract}
ABSTRAK
Kerentanan adalah keadaan atau kondisi yang dapat mengurangi kemampuan masyarakat untuk mempersiapkan diri menghadapi bahaya atau ancaman bencana. Tujuan dari mengetahui kerentanan adalah untuk mengurangi kemungkinan dampak yang merugikan yang diakibatkan oleh bencana. Rumusan masalah dalam penelitian ini adalah bagaimana membandingkan metode fuzzy mamdani dan fuzzy sugeno untuk mendeteksi daerah rentan banjir di Kecamatan Pringsewu. Dengan dibangunnya prototipe untuk menentukan daerah rentan banjir pada Kecamatan Pringsewu, ini dapat dijadikan upaya untuk mengurangi resiko banjir baik melalui pembangunan fisik maupun penyadaran dan peningkatan kemampuan menghadapi bencana. Penelitian ini menghasilkan simpulan yaitu aman, rentan dan banjir. Untuk perhitungan dimulai dengan menentukan himpunan fuzzy masing-masing variabel, pembentukan aturan fuzzy (implikasi), komposisi aturan menggunakan fungsi MAX, penegasan (defuzzifikasi). Sementara dalam prototipe dimulai menggunakan Graphic User Interface, kemudian dilakukan melengkapi kode pada sofware Matlab R2013a agar desain deteksi kerentanan dapat berfungsi. Setelah prototipe deteksi kerentanan banjir berhasil dibuat, data monografi Kecamatan Pringsewu dapat diinputkan kedalam prototipe. Selanjutnya akan diproses menggunakan metode Fuzzy Inference System yang telah dimasukan kedalam prototipe, kemudian hasil akan muncul dan hasil akhir metode Mamdani memiliki nilai akurasi 70\% dan metode Sugeno memiliki nilai akurasi 48,33\%. Sehingga dari hasil pengujian tersebut, menunjukan bahwa metode Mamdani lebih baik akurasinya dibandingkan dengan metode Sugeno.
\end{abstract}

Kata Kunci: Bencana, Banjir, Fuzzy mamdani, Fuzzy Sugeno, Matlab, Graphic User Interface 


\section{PENDAhUluan}

Sebagai Kabupaten baru, Kabupaten pringsewu mengalami perkembangan dan pembangunan setiap tahunya dengan cepat. Seperti kota-kota besar lainnya, Akibat dari pembangunan maka ruang terbuka hijau menjadi berkurang, karena alih fungsi lahan untuk mendukung kelancaran kegiatan ekonomi dan aktivitas di Kabupaten Pringsewu. Semakin banyak lahan yang tertutup jalan dan bangunan, sehingga daerah resapan air dalam tanah menjadi berkurang. Akibatnya banjir di wilayah Kabupaten Pringsewu sering terjadi. Kasus banjir terbesar di Kabupaten Pringsewu terjadi pada tahun 2010 yaitu 38 kasus banjir, maka perlu dilakukan mitigasi bencana. Mitigasi adalah serangkaian upaya untuk mengurangi risiko bencana, baik melalui pembangunan fisik maupun penyadaran dan peningkatan kemampuan menghadapi ancaman bencana (UU No.24 Pasal 1 No. 06 Tahun 2007-[12]). Permasalahan yang ada di Kabupaten Pringsewu khususnya pada Kecamatan Pringsewu, proses deteksi daerah rentan banjir pada Kecamatan Pringsewu selama ini dilakukan pasca terjadinya bencana banjir. Salah satu upaya sebagai mitigasi bencana, perlu dilakukan deteksi pra bencana melalui pendekatan dengan metodologi penelitian fuzzy Mamdani dan Sugeno. Penelitian ini melakukan perbandingan dua metode fuzzy yaitu, metode fuzzy Mamdani dan Sugeno dengan menggunakan data monografi di Kecamatan Pringsewu yaitu kepadatan penduduk, drainase aliran sungai, kelerengan wilayah, ketinggian wilayah dan curah hujan. Penelitian ini akan menghasilkan prototipe deteksi daerah rentan banjir yang dibangun menggunakan sofware Matlab R2013a berbasis fuzzy inference system, prototipe dibangun dari hasil analisa perbandingan metode Fuzzy Mamdani dan Sugeno, yang menerapkan metode fuzzy Mamdani dengan nilai akurasi yang paling baik.

\section{LANDASAN TEORI}

\subsection{Pengertian Bencana}

Berdasarkan UU RI Nomor 24 Tahun 2007 tentang Penanggulangan Bencana bahwa bencana adalah peristiwa atau rangkaian peristiwa yang mengganggu kehidupan dan penghidupan masyarakat, disebabkan oleh faktor alam dan non alam maupun faktor manusia sehingga mengakibatkan timbulnya korban jiwa manusia, kerusakan lingkungan kerugian harta dan dampak psikologi.

Aisyah Journal of Informatics and Electrical Engineering

\subsection{Pengertian Banjir}

Banjir adalah tinggi muka air melebihi normal pada sungai dan biasanya mengalir meluap melebihi tebing sungai dan luapan artinya menggenang pada suatu daerah genangan (Hadisusanto, 2011:19-[6]). Banjir menjadi masalah dan berkembang menjadi bencana ketika banjir tersebut mengganggu aktivitas manusia dan bahkan membawa korban jiwa dan harta benda (Sobirin,2009:9-[14]).

Pengendalian banjir adalah pencegahan limpasan air di atas permukaan tanah, khususnya tanah terendah, dan pengurangan aliran dalam saluran alami atau sungai selama dan sesudah hujan besar. Pengendalian banjir ini merupakan salah satu fase masalah teknik yang terlibat di dalam pengawetan tanah dan air (Hardjoamidjojo dan Sukartaatmadja, 1992:56-[7]).

\subsection{Definisi Logika Fuzzy}

Logika Fuzzy merupakan salah satu komponen pembentuk soft computing.Logika fuzzy pertama kali diperkenalkan oleh Prof. Lotfi A. Zadeh pada tahun 1965. Dasar logika fuzzy adalah teori himpunan fuzzy.Pada teori himpunan fuzzy, peranan derajat keanggotaan sebagai penentu keberadaan elemen dalam suatu himpunan sangatlah penting. Nilai keanggotaan atau derajat keanggotaan atau membership function menjadi ciri utama dari penalaran dengan logika fuzzy tersebut.

\subsection{Sistem Iferensi Metode Fuzzy Mamdani}

Metode Mamdani sering juga dikenal dengan nama metode min-max. Metode ini diperkenalkan oleh Ebrahim Mamdani pada tahun 1975. Untuk mendapatkan output diperlukan 4 tahapan, yaitu :

1. Pembentukan himpunan fuzzy Pada metode Mamdani baik variabel input maupun variabel output dibagi menjadi satu atau lebih himpunan fuzzy.

2. Aplikasi fungsi implikasi Pada Metode Mamdani, fungsi implikasi yang digunakan adalah min.

3. Komposisi aturan Metode yang digunakan dalam melakukan inferensi sistem fuzzy, yaitu Metode max (maximum). Secara umum dapat dituliskan : $\mu \mathrm{sf}[\mathrm{Xi}]=\max (\mu \mathrm{sf}[\mathrm{Xi}], \mu \mathrm{kf}[\mathrm{Xi}])$ Dengan $: \mu \mathrm{sf}[\mathrm{Xi}]$ $=$ nilai keanggotaan solusi fuzzy sampai aturan ke $\mathrm{i}$ 
$\mu \mathrm{kf}[\mathrm{Xi}])=$ nilai keanggotaan konsekuan fuzzy aturan ke $\mathrm{i}$

4. Penegasan (defuzzy) Defuzzifikasi pada komposisi aturan mamdani dengan menggunakan metode centroid. Dimana pada metode ini, solusi crisp diperoleh dengan cara mengambil titik pusat daerah fuzzy. Secara umum dirumuskan:

$$
\begin{gathered}
z^{*}=\frac{\int_{z} z \mu(z) d z}{\int_{z} \mu(z) d z} \\
z^{*}=\frac{\sum_{j=1}^{n} z j \mu(z j)}{\sum_{j=1}^{n} \mu(z j)}
\end{gathered}
$$

\subsection{Sistem Iferensi Metode Fuzzy Sugeno}

Logika Fuzzy Sugeno hampir sama dengan metode Mamdani, hanya saja output (konsekuen) system tidak berupa himpunan fuzzy tetapi berupa konstanta/persamaan linier. Metode ini dikembangkan oleh Takagi Sugeno Kang pada tahun 1985. Metode TSK (Sugeno) ini terdiri dari 2 jenis, yaitu :

1. Metode Fuzzy Sugeno Orde Nol

Secara umum, model ini adalah :

$\operatorname{IF}\left(X_{1}\right.$ is $\left.A_{1}\right)$ o. $\left(X_{2}\right.$ is $\left.A_{2}\right)$ o. $\left(X_{3}\right.$ is $\left.A_{3}\right)$ o . . o $\left(X_{n}\right.$ is $\left.A_{n}\right)$ THEN $z=k$

dengan :

$\mathrm{A}_{1}$ adalah himpunan fuzzy ke-i sebagai anteseden

$\mathrm{k}$ adalah konstanta (tegas) sebagai konsekuen

2. Metode Fuzzy Sugeno Orde Satu

Secara umum, bentuk model ini adalah :

$\operatorname{IF}\left(\mathrm{X}_{1}\right.$ is $\left.\mathrm{A}_{1}\right)$ o . . o $\left(\mathrm{X}_{\mathrm{n}}\right.$ is $\left.\mathrm{A}_{\mathrm{n}}\right)$ THEN $\mathrm{z}=\mathrm{p}_{1} * \mathrm{x}_{1}+\ldots$ $+\mathrm{p}_{\mathrm{n}} * \mathrm{x}_{\mathrm{n}}+\mathrm{q}$

dengan :

$A_{1}$ adalah himpunan fuzzy ke-i sebagai anteseden

$\mathrm{p}_{1}$ adalah konstanta (tegas) ke-i

q adalah konstanta dalam konsekuen

Jika kita menggunakan Logika Fuzzy Sugeno, maka deffuzifikasi dilakukan dengan cara mencari nilai rata-ratanya.

\subsection{Tinjauan Studi}

Ada beberapa penelitian yang menerapkan metode fuzzy diantaranya : Penelitian yang dilakukan oleh Arief L.N. Purnama B.S. dan Trias Aditya mengenai pemetaan resiko bencana banjir Rob Kota Semarang.
Berdasarkan proses penelitian ini, pemodelan kerentanan dapat didekatkan dengan menggunakan metode fuzzy logic mamdani dimana memberikan hasil yang baik dalam proses penilaian risiko banjir rob kota Semarang (Arief L.N.2012-[3]). Kemudian penelitian Sri Ayu Subekti, meneliti tentang penggunaan metode fuzzy Mamdani dan Sugeno untuk pengambilan keputusan dalam analisis kredit. Dimana Metode sugeno dapat menentukan diterima atau ditolaknya suatu pengajuan kredit dan dapat mengurangi kredit macet. (Sri Ayu Subekti.2013-[15]). Penelitian yang dilakukan oleh Rabiatul Adawiah dan Ruliah melakukan penelitian sistem pendukung keputusan pemilihan penerimaan beasiswa pada STMIK Banjar baru kampus Banjarmasin. Dipenelitian yang dilakukan oleh penulis, penulis membandingkan hasil dari perhitungan Fuzzy Mamdani dengan AHP. Setelah melihat hasil dari perhitungan tersebut, Fuzzy Mamdani mendapatkan hasil yaitu sebesar $85,7 \%$ sedangkan perhitungan AHP yaitu 14,3\%. Dilihat pada hasil perhitungan, metode Fuzzy Mamdani dapat digunakan untuk pemilihan jurusan. (Rabiatul Adawiyah dan Ruliah.2013-[1]). Dan yang terakhir adalah penelitian yang dilakukan oleh Alshalaa A shleeg dan Ismail M ellabib. Dalam penelitian ini, dgunakan logika Fuzzy yang paling dikenal yakni Mamdani dan Sugeno. Kedua metode ini mampu menghasilkan system untuk mendiagnosa kakner payudara. Hanya saja performansi operasional dengan metode sugeno lebih baik daripada metode mamdani.. (Alshalaa A Shleed.dkk.2013-[2]).

\section{METODOLOGI DAN RANCANGAN PENELITIAN}

\subsection{Pemilihan Sampel}

Populasi data yang akan digunakan dalam penelitian adalah data monografi Kecamatan Pringsewu meliputi kepadatan penduduk, drainase aliran sungai, kelerengan wilayah, ketinggian wilayah dan curah hujan. Data tersebut akan dijadikan parameter untuk menentukan daerah rentan banjir pada Kecamatan Pringsewu.

\subsection{Pengumpulan Data}

Metode pengumpulan data yang digunakan dalam penelitian ini adalah dokumentasi, dalam penelitian ini sumber tertulis berdasarkan dokumen yang ada di 
kantor Kecamatan Pringsewu. Studi pustaka dengan mempelajari, meneliti dan membaca buku, jurnal, skripsi, tesis yang berhubungan dengan metodologi penelitian, observasi yang dilakukan dengan mengamati langsung secara sistematik terhadap gejala atau fenomena yang terjadi dilapangan. Hal ini bertujuan mengetahui daerah-daerah yang sering terjadi banjir. Wawancara, menghasilkan berupa data karakteristik banjir yang dilakukan tanya jawab langsung dengan informan.

\subsection{Teknik Analisis dan Pengujian}

Penelitian yang akan dilakukan menggunakan metodemetode fuzzy Mamdani dan Sugeno. Metode-metode tersebut akan digunakan untuk mengolah data monografi Kecamatan Pringsewu berupa kepadatan pendudk, drainase aliran sungai, kelerengan wilayah, ketinggian wilayah dan curah hujan. Hasil pengolahan data tersebut akan mendapatkan himpunan input fuzzy dan output daerah rentan banjir. Metode fuzzy Mamdani dan Sugeno akan dibandingkan untuk mendapatkan metode terbaik untuk diterapkan dalam perancangan prototipe sistem.

\subsection{Langkah-Langkah Penelitian}

Langkah-langkah yang dilakukan dalam penelitian ini :

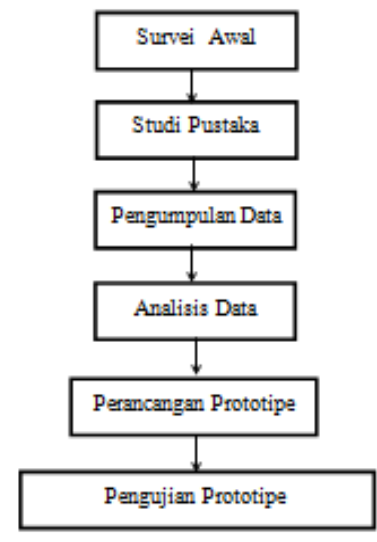

Gambar 1 Langkah-langkah Penelitian

\section{Hasil dan Pembahasan}

\subsection{Komposisi Aturan Mamdani}

Komposisi aturan fungsi implikasi menggunakan $M A X$ yaitu dengan cara mengambil nilai maksimum dari output aturan. Jika semua proposisi telah dievaluasi, maka output akan berisi himpunan fuzzy yang mereflesikan konstribusi dari tiap-tiap proposisi. Komposisi aturan untuk sample sebelumnya adalah : Metode Max digunakan untuk mentukan komposisi aturan.

Variabel output :

Derajat kebenaran himpunan Rentan

$$
\begin{aligned}
& =\operatorname{Max}(\alpha 497 ; \alpha 521 ; \alpha 533) \\
& =\operatorname{Max}(0,333 ; 0,25 ; 0,25) \\
& =0,333
\end{aligned}
$$

Derajat kebenaran himpunan Banjir

$=\operatorname{Max}(\alpha 485 ; \alpha 486 ; \alpha 498 ; \alpha 522 ; \alpha 534)$

$=\operatorname{Max}(0,667 ; 0,3 ; 0,3 ; 0,25 ; 0,25)$

$=0,667$

Berdasrakan fungsi keanggotaan dari variabel output himpunan rentan pada saat $\alpha 497$

diperoleh nilai $0,33 \mathrm{~d}(497)$ sebagai berikut :

$$
\begin{array}{r}
\mathrm{M}_{\mathrm{R}}(\mathrm{d} 497)=\alpha 497 \longleftrightarrow \frac{d(497)-10}{20-10}=0,333 \\
\mathrm{~d}(497)-10=3,333 \\
\mathrm{~d}(497)=13,333 \\
\mathrm{M}_{\mathrm{R}}(\mathrm{d} 497)=\alpha 497 \longleftrightarrow \frac{d(497)-40}{50-40}=0,333 \\
\mathrm{~d}(497)-40=3,333 \\
\mathrm{~d}(497)=43,333
\end{array}
$$

Berdasrakan fungsi keanggotaan dari variabel output himpunan rentan pada saat $\alpha 485$ diperoleh nilai $0,667 \mathrm{~d}(485)$ sebagai berikut :

$$
\begin{array}{r}
M_{R}(\mathrm{~d} 485)=\alpha 485 \longleftrightarrow \frac{d(485)-40}{50-40}=0,667 \\
\mathrm{~d}(485)-40=6,667 \\
\mathrm{~d}(485)=46,667
\end{array}
$$

Modifikasi Fungsi keanggotaan tinggi dari variable output setelah diterapkan acut adalah: 
$\mathrm{M}(\mathrm{x})=\left\{\begin{array}{lr}(0,1 x-1) ; & 10 \leq d_{497} \leq 13,33 \\ 0,333 ; & 13,33<d_{497} \leq 43,33 \\ (0,1 x-4) ; & 43,33<d_{497}, d_{485} \leq 46,67 \\ 0,667 ; & 46,67<d_{485} \leq 100\end{array}\right.$

\subsection{Defuzzifikasi}

Pada tahap defuzzifikasi, terdapat perbedaan antara Fuzzy Mamdani dan Fuzzy Sugeno. Untuk Fuzzy Mamdani, proses perhitungan defuzzifikasi dilakukan dengan metode cetroid :

$$
\begin{aligned}
& \mathrm{Z}^{*}=\frac{\int_{Z} z \mu(z) d z}{\int_{z} \mu(z) d z} \\
& \mathrm{Z}^{*}=\frac{\mathrm{M}_{1}+\mathrm{M}_{2}+\mathrm{M}_{3}+\mathrm{M}_{4}}{\mathrm{~L}_{1}+\mathrm{L}_{2}+\mathrm{L}_{3}+\mathrm{L}_{4}} \\
& \mathrm{M}_{1}=\int_{10}^{13,33}(0,1 \cdot \mathrm{x}-1) \cdot \mathrm{xdx}=6,32 \\
& \mathrm{M}_{2}=\int_{13,33}^{43,33}(0,333 \cdot \mathrm{x}) \mathrm{dx}=283,0167 \\
& \mathrm{M}_{3}=\int_{43,33}^{466,67}(0,1 \cdot x-4) \cdot x d x=68,69 \\
& \mathrm{M}_{4}=\int_{46,67}^{100}(0,667 \cdot x d x=2605,34 \\
& \mathrm{L}_{1}=\int_{10}^{13,33}(0,1 \cdot \mathrm{x}-1) \mathrm{dx}=0,33 \\
& \mathrm{~L}_{2}=\int_{13,33}^{43,33}(0,33 d x=9,99 \\
& \mathrm{L}_{3}=\int_{43,33}^{46,67}(0,1 \cdot \mathrm{x}-4) d x=68,69 \\
& \mathrm{~L}_{4}=\int_{46,67}^{100}(0,667 \mathrm{dx}=35,37
\end{aligned}
$$

Nilai crisp output dihitung dengan:

$$
\begin{aligned}
& Z *=\frac{6,32+283,0617+68,69+2605,34}{0,03+9,99+68,69+35,37} \\
& =\frac{2963,367}{47,78} \\
& =62,02
\end{aligned}
$$

Batasan nilai output adalah :

1. Penilaian "AMAN" : batas nilai output $<15$
2. Penilaian "RENTAN" : batas nilai output $15 \leq \mathrm{x} \leq$ 45

3. Penilaian "Banjir" : batas nilai output $>45$

Jadi disimpulkan dengan data-data yang ada dan setelah dianalisis, data yang dijadikan sample dikatagorikan memeberikan penilaian daerah rentan banjir dengan nilai 62,02 .

Sementara untuk fuzzy Sugeno, proses perhitungan defuzzifikasi dilakukan dengan rumus :

dimana :

$$
\mathrm{Z}=\frac{\sum_{i=1}^{n} W i Z i}{\sum_{i=1}^{n} W i}
$$

Wi adalah hasil proses operasi fuzzy logic antecedent $\mathrm{Zi}$ adalah keluaran rule ke-1

$\mathrm{Z}=$

$\frac{(0,667 \times 70)+(0,3 \times 70)+(0,333 \times 45)+(0,3 \times 70)+(0,25 \times 45)+(0,25 \times 70)+(0,25 \times 45)+(0,25 \times 70)}{0,667+0,3+0,333+0,3+0,25+0,25+0,25+0,25}$ $0,667+0,3+0,333+0,3+0,25+0,25+0,25+0,25$

$=\frac{161,175}{2,60}$

$=61,99038$

Jadi disimpulkan dengan data-data yang ada dan setelah dianalisis, data yang dijadikan sample dikatagorikan memeberikan penilaian daerah rentan banjir dengan nilai 61,99038 .

\subsection{Uji Coba GUI}

Uji coba GUI dibuat menggunakan program Matlab R2013a. Gambar dibawah ini adalah form utama dari sistem yang telah dibuat dalam menentukan daerah rentan banjir di Kecamatan Pringsewu

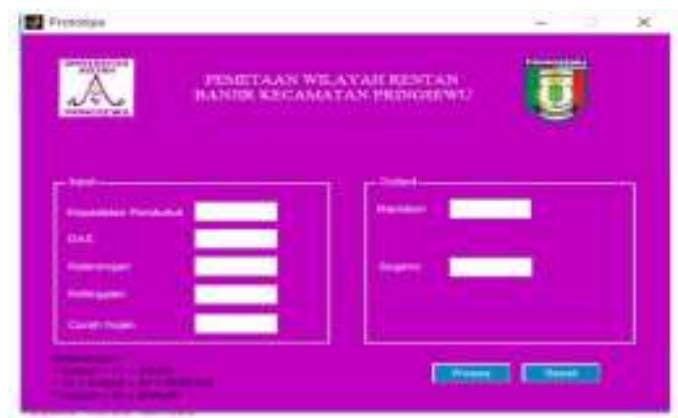




\section{Gambar 2 Prototipe Penilaian Daerah Rentan Banjir}

1. Hasil Mamdani jika dalam script matlab > fis=readfis('PswuMamdani.fis')

fis $=$

name: 'PswuMamdani'

type: 'mamdani'

andMethod: 'min'

orMethod: 'max'

defuzzMethod: 'centroid'

impMethod: 'min'

aggMethod: 'max'

input: [1x5 struct]

output: [1x1 struct]

rule: [1x720 struct]

>> out=evalfis([430 14251012 25],fis)

out $=$

30

2. Hasil Mamdani jika dalam script matlab > fis=readfis('PswuSugeno.fis')

fis $=$

name: 'PswuSugeno'

type: 'sugeno'

andMethod: 'prod'

orMethod: 'probor'

defuzzMethod: 'wtaver'

impMethod: 'prod'

aggMethod: 'sum'

input: $[1 \times 5$ struct $]$

output: [1x1 struct]

rule: $[1 \times 720$ struct]
>> out=evalfis([430 14251012 25],fis)

$$
\text { out }=
$$

45

\subsection{Perbandingan dan Validasi Metode Fuzzy Mamdani dan Sugeno}

Setelah dilakukan perhitungan sampel data sebanyak 60 kali percobaan, maka akan dilakukan komparasi antara metode Mamdani dan metode Sugeno dengan data asli dari objek penelitian sebagai acuan. Setelah dilakukan komparasi akan dilihat keakurasian hasil sebagai berikut :

\section{Tabel 1 Tabel Perbandingan dan Validasi Metode} Fuzzy Mamdani dan Sugeno

\begin{tabular}{|c|l|l|c|}
\hline \multirow{2}{*}{ NO } & \multicolumn{2}{|c|}{ Penilaian Kinerja } & \multirow{2}{*}{ Data } \\
\cline { 2 - 4 } & \multicolumn{1}{|c|}{ Mamdia } \\
\hline 1 & Banjir (72.6757) & Banjir (70) & Banjir \\
\hline 2 & Banjir (72.6757) & Banjir (70) & Banjir \\
\hline 3 & Banjir (72.6757) & Banjir (70) & Banjir \\
\hline 4 & Banjir (72.6757) & Banjir (70) & Banjir \\
\hline 5 & Banjir (72.6757) & Banjir (70) & Rentan \\
\hline 6 & Banjir (71.8924) & Banjir (70) & Banjir \\
\hline 7 & Banjir (65.2298) & Banjir (63.75) & Rentan \\
\hline 8 & Banjir (72.6757) & Banjir (70) & Rentan \\
\hline 9 & Rentan (30) & Banjir (45) & Aman \\
\hline 10 & Rentan (30) & Banjir (45) & Aman \\
\hline 11 & Banjir (71.8924) & Banjir (70) & Aman \\
\hline 12 & Banjir (65.2298) & Banjir (70) & Banjir \\
\hline 13 & Banjir (72.6757) & Banjir (70) & Banjir \\
\hline 14 & Banjir (56.4889) & Banjir (54.375) & Rentan \\
\hline 15 & Banjir (72.6757) & Banjir (70) & Rentan \\
\hline 16 & Banjir (72.6757) & Banjir (70) & Banjir \\
\hline 17 & Banjir (56.4889) & Banjir (70) & Banjir \\
\hline 18 & Banjir (72.6757) & Banjir (70) & Banjir \\
\hline
\end{tabular}




\begin{tabular}{|c|c|c|c|}
\hline 19 & Banjir (72.6757) & Banjir (70) & Banjir \\
\hline 20 & Rentan (30) & Banjir (45) & Rentan \\
\hline 21 & Banjir (60) & Banjir(65.8333) & Banjir \\
\hline 22 & Rentan (30) & Banjir (45) & Rentan \\
\hline 23 & Rentan (30) & Banjir (45) & Rentan \\
\hline 24 & Rentan(27.3443) & Rentan (37.5) & Aman \\
\hline 25 & Rentan(23.5208) & Rentan (30) & Aman \\
\hline 26 & Rentan (30) & Banjir (45) & Aman \\
\hline 27 & Banjir (72.6757) & Banjir (70) & Banjir \\
\hline 28 & Banjir (72.6757) & Banjir (70) & Banjir \\
\hline 29 & Rentan (30) & Banjir (45) & Rentan \\
\hline 30 & Rentan (30) & Banjir (45) & Rentan \\
\hline 31 & Banjir (72.6757) & Banjir (70) & Banjir \\
\hline 32 & Banjir (72.6757) & Banjir (70) & Banjir \\
\hline 33 & Banjir (72.6757) & Banjir (70) & Banjir \\
\hline 34 & Banjir (72.6757) & Banjir (70) & Banjir \\
\hline 35 & Rentan (30) & Banjir (45) & Rentan \\
\hline 36 & Banjir (62.4969) & Banjir (61.6667) & Banjir \\
\hline 37 & Rentan (30) & Banjir (45) & Rentan \\
\hline 38 & Rentan (30) & Banjir (45) & Rentan \\
\hline 39 & Aman (8.00797) & Rentan (15) & Aman \\
\hline 40 & Aman (7.90909) & Rentan (15) & Aman \\
\hline 41 & Rentan (30) & Banjir (45) & Aman \\
\hline 42 & Banjir (66.7891) & Banjir (65) & Banjir \\
\hline 43 & Banjir (72.6757) & Banjir (70) & Banjir \\
\hline 44 & Rentan (30) & Banjir (45) & Rentan \\
\hline 45 & Rentan (30) & Banjir (45) & Rentan \\
\hline 46 & Banjir (72.6757) & Banjir (70) & Banjir \\
\hline 47 & Banjir (72.6757) & Banjir (70) & Banjir \\
\hline 48 & Rentan (30) & Banjir (45) & Banjir \\
\hline 49 & Rentan (30) & Banjir (45) & Banjir \\
\hline 50 & Rentan (30) & Banjir (45) & Rentan \\
\hline
\end{tabular}

\begin{tabular}{|c|l|l|c|}
\hline 51 & Rentan (30) & Banjir (45) & Banjir \\
\hline 52 & Rentan (30) & Banjir (45) & Rentan \\
\hline 53 & Rentan (30) & Banjir (45) & Rentan \\
\hline 54 & Aman (8.00797) & Rentan (15) & Aman \\
\hline 55 & Aman (7.90909) & Rentan (15) & Aman \\
\hline 56 & Rentan (30) & Banjir (45) & Aman \\
\hline 57 & Rentan (30) & Banjir (45) & Banjir \\
\hline 58 & Rentan (30) & Banjir (45) & Banjir \\
\hline 59 & Rentan(26.4548) & Rentan (37.5) & Rentan \\
\hline 60 & Rentan (30) & Banjir (45) & Rentan \\
\hline
\end{tabular}

\subsection{Hasil Akurasi}

Pengertian akurasi adalah seberapa dekat suatu angka hasil pengukuran terhadap angka atau data sebenarnya. Jadi, akurasi yang dimaksud dalam penelitian ini adalah angka hasil pengukuran, yaitu nilai dari metode Mamdani dan metode Sugeno yang menunjukan hasil output yang benar berdasarkan data yang berasal dari objek penelitian. Jika nilai output pada perhitungan fuzzy Mamdani dan fuzzy Sugeno lebih kecil dari 15, maka daerah tersebut dinyatakan "AMAN" atau dinotifikasikan sebagai berikut : $\mathrm{x}<15$ = "Aman". Jika nilai output pada perhitungan fuzzy Mamdani dan fuzzy Sugeno lebih besar dari 15 dan lebih kecil dari 45, maka daerah tersebut dinyatakan "RENTAN" atau dinotifikasikan sebagai berikut : $15 \leq \mathrm{x} \leq 45=$ "RENTAN". Jika nilai output pada perhitungan fuzzy Mamdani dan fuzzy Sugeno lebih besar dari 45, maka daerah tersebut dinyatakan "BANJIR" atau dinotifikasikan sebagai berikut : $x \geq 45=$ "BANJIR".

Berdasarkan hasil dari tabel III.1 maka dapat dilihat nilai fuzzifikasi antara metode mamdani dan metode sugeno yang memiliki kategori sama dengan data asli, sehingga hasil komparasi adalah sebagai berikut :

1. Metode Mamdani menghasilkan tingkat akurasi total $70 \%$ dari 60 kali percobaan

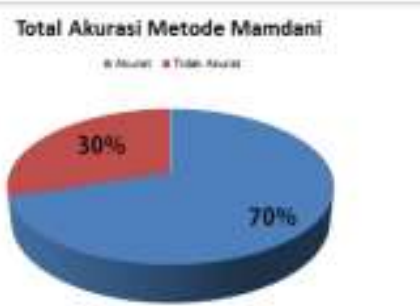




\section{Gambar 3 Grafik Total Akurasi Metode Mamdani}

2. Sedangkan untuk metode Sugeno menghasilkan total tingkat akurasi 48,33\% dari 60 kali percobaan

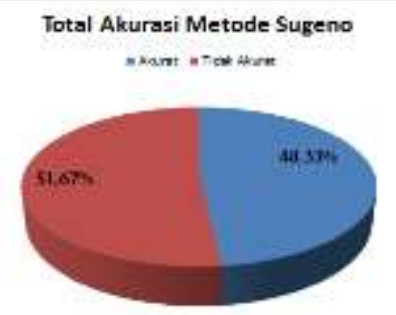

\section{Gambar 4 Grafik Total Akurasi Metode Mamdani}

Sehingga dari hasil pengujian tersebut, menunjukan bahwa metode Mamdani lebih baik akurasinya dibandingkan dengan metode Sugeno.

\section{KESIMPULAN}

Dari hasil penelitian deteksi daerah rentan banjir di Kecamatan Pringsewu menggunakan perbandingan dua metode, yaitu metode Fuzzy Mamdani dan Sugeno. Dapat ditarik simpulan sebagai berikut :

1. Berdasarkan hasil evaluasi dan validasi, diperoleh hasil bahwa metode fuzzy Mamdani mendapatkan nilai akurasi data tertinggi setelah divalidasi dengan data asli yaitu $70 \%$, sedangkan metode fuzzy Sugeno mendapatkan nilai $48 \%$. Sehingga metode fuzzy mamdani lebih baik dari Sugeno, dan dapat digunakan dalam mendeteksi daerah rentan banjir di Kecamatan Pringsewu.

\section{DAFTAR PUSTAKA}

[1] Adawiyah, Rabiatul dan Ruliah. (2013). Sistem Pendukung Keputusan Pemilihan Penerima Beasiswa Berbasis Fuzzy Mamdani. ISSN: 02163284, Banjarbaru: Sekolah Tinggi Manajemen Informatika dan Komputer Banjarbaru

[2] Alshala. A shleeg, dan Ismail.M Ellabib. (2013). Computer Engineering Departement University of Tripoli, "Comparision of Mamdani and Sugeno Fuzzy Inference System for the Breast Cancer
Risk", International Journal of Computer Information Mechatronic System Science And Engenering, Vol,7 No.10, 2013.

[3] Arief L.N., Purnama B.S., Trias Aditya (2012). Pemetaan Risiko Bencana Banjir Rob Kota Semarang. Semarang: The 1st Conference on Geospatial Information Science and Engineering

[4] BAKORNAS PB. (2002). Arahan Kebijakan Mitigasi Bencana Perkotaan di Indonesia. Jakarta

[5] Himbawan, Gigih. (2010). Penyebab Tetap Bermukimnya Masyarakat di Kawasan Rawan Banjir Kelurahan Tanjung Agung Kota Bengkulu. Tesis: Universitas Diponegoro, Semarang.

[6] Hadisusanto, N. (2011) Aplikasi Hidrologi. Jogjakarta : Jogja Mediautama

[7] Hardjoamindo, S. dan Sukartaadmadja, S. 1992. Teknik pengawetan Tanah dan Air. JICA IPB. Bogor

[8] Khomarudin, Rokhis. (2015). Bunga Rampai Pemanfaatan Data Penginderaan Jauh untuk Mitigasi Bencana Banjir. Bogor: PT. Penerbit IPB Pres

[9] Kusumadewi, Sri. (2002). Analisis Desain Sistem Fuzzy Menggunakan Tool Box Matlab. Jogjakarta: Graha Ilmu.

[10] Moedjiono, (2016). Metodologi Penelitian dan Laporan Penyusunan Tugas Akhir-Tesis dan Paper untuk jurusan Informatika dan Ilmu Komputer.

[11] Ned, Gell. dan Roger. Jang. (2000). Fuzzy Logic Toolbox, Mathwork Inc.

[12] Republik Indonesia (2007). Undang-Undang nomor 24 Tahun 2007 Tentang Penanggulangan Bencana. Lembaran Negara Republik Indonesia.

[13] Sesulih, Putri Setiajeng, Sesulihatien, Wahjoe Tjatur, dan Fariza, Arna. (2011). Sistem Manajemen Banjir Terintegretasi ( Sub Bab : Emergency dan Evakuasi Dengan Logika Fuzzy), Surabaya: Politeknik Elektronika Negeri 
[14] Sobirin, S. (2009). Kajian Strategis Solusi Banjir Cekungan Bandung. Disampaikan seminar nasional Teknik Sumber Daya Air : Peran Masyarakat, Pemerintah dan Swasta sebagai Jejaring Dalam Mitigasi Daya Rusak Air. Bandung: 11 Agustus 2009.

[15] Sriayu, Subekti. (2014). Penggunaan Metode Fuzzy Mamdani dan Sugeno Untuk Pengambilan Keputusan Dalam Analisa Kredit. Tugas Akhir: Universitas Kristen Satya Wacana

[16] Suherlan, E. (2001). Zonasi Tingkat Kerentangan Banjir Kabupaten Bandung Menggunakan System Informasi Geografis. Skripsi: IPB, Bogor. 